\title{
PENGARUH SENAM LANSIA TERHADAP TINGKAT DEPRESI LANSIA PENDERITA HIPERTENSI
}

\author{
Atiek Murharyati ${ }^{1)}$, Wahyuningsih Safitri ${ }^{2)}$ Erinda Nur Pratiwi ${ }^{3)}$, Adhi Wardhana \\ Amrullah ${ }^{4)}$, Heni Nur Kusumawati ${ }^{5)}$, Hanugrah Ardya Crisdian $S^{6}$ ) \\ 1,2,3,4,6 Universitas Kusuma Husada Surakarta \\ ${ }^{5}$ Poltekkes Kemenkes Surakarta \\ email korespondensi: murharyatiatik@gmail.com
}

\begin{abstract}
ABSTRAK
Penyakit yang dialami lansia seringkali memperberat tingkat depresi lansia. Penyakit kronis yang sering dijumpai di lansia adalah hipertensi. Tujuan penelitian untuk mengetahui pengaruh senam lansia terhadap tingkat depresi lansia penderita hipertensi. Metode penelitian dengan quasy experiment dengan design penelitian one group pre and post test without control. Teknik sampling menggunakan total sampling yaitu sejumlah 24 orang lansia. Analisa data menggunakan uji paired t test. Hasil uji analisis paired sample t-test pada data pre dan post senam lansia menunjukkan nilai $p$ value 0,000 artinya terdapat pengaruh senam lansia terhadap tingkat depresi lansia penderita hipertensi. Kesimpulannya adalah lansia penderita hipertensi membutuhkan kegiatan aktifitas fisik seperti senam lansia sehingga dapat mencegah depresi yang bisa memperberat kondisi lansia.
\end{abstract}

Kata kunci: depresi lansia; hipertensi; senam lansia

\begin{abstract}
Diseases experienced by the elderly often complicate the depression level of the elderly. A chronic disease that is often found in the elderly is hypertension. The purpose of the study was to determine the effect of elderly exercise on the level of depression in elderly patients with hypertension. The research method is a quasiexperimental research design with one group pre and post test without control. The sampling technique used a total sampling of 24 elderly people. Data analysis using paired t test. The results of the paired sample $t$-test analysis on the pre and post elderly exercise data showed a p value of 0.000 , meaning that there was an influence of elderly exercise on the level of depression in elderly patients with hypertension. The conclusion is that elderly people with hypertension need physical activities such as elderly gymnastics so that they can prevent depression which can aggravate the condition of the elderly.
\end{abstract}

Keywords: elderly depression; hypertension; elderly gymnastics

\section{PENDAHULUAN}

Lansia merupakan kelompok manusia yang berusia 60 tahun keatas (Nurwahidah, 2010). Permasalahan yang muncul pada para lanjut usia yaitu proses menua yang terjadi secara alami yang menimbulkan adanya masalah fisik, mental, serta sosial. Kesehatan mental lansia seringkali menambah berat beban keluarga dan masyarakat. Beberapa jenis kesehatan mental yang biasa dijumpai adalah demensia, delirium, dan depresi. Depresi pada lansia yaitu kondisi terganggunya fungsi yang ada dari diri seseorang, berkaitan alam perasaan seperti rasa sedih serta gejala lain yang menjadi penyertanya. Depresi merupakan kondisi adanya gangguan perasaan seperti adanya perasaan sedih, merasa sendiri, rendah diri, mudah putus asa, dan terdapat tanda retardasi psikomotor atau kadang-kadang agitasi, menarik diri dan terdapat gangguan vegetatif 
seperti insomnia dan anoreksia (Novayanti et al., 2020). Depresi merupakan kumpulan gejala yang kompleks dengan manifestasi beragam, dan yang sering dijumpai adalah insomnia, konstipasi, disertai penurunan kondisi kesehatan.

Hasil laporan Riskesdas tahun 2013, diperolah hasil prevalensi lansia yang mengalami depresi adalah lansia berusia 5564 tahun sebesar $15,9 \%$, lansia usia 65-74 tahun sebesar $23,2 \%$, dan lansia usia diatas 75 tahun sebesar 33,7\% (Kementerian Kesehatan RI, 2018). Prevalensi lansia di Jawa Tengah yang mengalami depresi berjumlah $12 \%$. Prevalensi depresi pada lansia usia 55-64 tahun sebesar 14,2\%, pada lansia usia 65-74 tahun sebesar 18,0\%, lansia usia $>75$ tahun sebesar 28,7\% (Santoso, B; Sulistiowati, E; Sekartuti; L, 2013)

Kejadian depresi pada lansia disebabkan oleh beberapa faktor salah satunya akibat proses penuaan secara alami sehingga menimbulkan penurunan fungsi tubuh yang berlanjut pada konsekuensi negatif (Livana et al., 2018). Kondisi penuaan yang dialami lansia dan penyakit yang dimiliki membuat lansia mengalami gangguan pada kondisi psikososialnya. Kondisi tersebut dapat terjadi karena adanya faktor kehilangan yang dapat menyebabkan masalah fungsional negatif lansia yang berupa terjadinya gangguan self esteem, sehingga mengakibatkan depresi (Rodgers, 2008)

Banyak kalangan berpendapat bahwa depresi pada lansia hanya semata mata karena penurunan proses menua, padahal patut diwaspadai bahwa keadaan itu erat hubungannya dengan adanya gangguan fisik atau kelainan psikososial. Beberapa gangguan fisik seringkali memperberat depresi pada lansia atau bisa menjadikan penyebab lansia menjadi depresi. Gangguan fisik yang seringkali terjadi pada lansia diantaranya adalah hipertensi.

Hipertensi disebut dengan silent killer yang mana memiliki gejala yang berbeda setiap individunya. Gejala-gejala tersebut adalah pusing disertai rasa berat ditengkuk, vertigo (pusing tujuh keliling), jantung terasa berdebar, mudah lelah, pandangan tampak kabur, telinga berdenging atau tinnitus dan bahkan mimisan (Kementerian
Kesehatan RI, 2018) Hipertensi salah satu dari penyakit kelainan jantung dan pembuluh darah yang ditandai dengan peningkatan tekanan darah. Seseorang disebut menderita hipertensi jika tekanan darah diatas 140/90 $\mathrm{mmHg}$ (Indah Prasetyaningrum, 2014)

Sekitar 1 dari 3 orang penduduk Indonesia menderita hipertensi. Hasil tersebut didasari dari pengukuran yang menunjukkan adanya persentase penderita hipertensi mengalami peningkatan seiring dengan bertambahnya usia. Hipertensi terjadi pada kelompok umur 31-44 tahun $(31,6 \%)$, umur $45-54$ tahun $(45,3 \%)$, umur 55-64 tahun $(55,2 \%)$ dan umur 65-74 tahun $63,2 \%$, dan tertinggi sebanyak $69,5 \%$ di usia lebih dari 75 tahun menderita hipertensi (Kementerian Kesehatan RI, 2018).

Salah satu faktor yang beresiko dalam menyebabkan hipertensi yaitu stres. Adanya stres dapat mengakibatkan peningkatkan denyut jantung sehingga berpotensi mengalami hipertensi (Kowalski, Robert E.; Burstein, 2010). Perubahan psikososial lansia terjadi akibat perubahan kognitif, adanya penyakit yang diderita, kehilangan peran sosial dapat mempengaruhi konsep diri lansia sehingga hal tersebut menjadi stressor, oleh karena itu lansia rentan mengalami masalah psikologis yang umum yaitu depresi (Putri \& Fitriyani, 2016). Depresi yang dialami lansia dapat dikurangi dengan beberapa metode diantaranya pendekatan bimbingan spiritual dan senam (Kurnianto, Syaifuddin dkk, 2011) (Kurnianto et al., 2019).

Penelitian sebelumnya menjelaskan bahwa senam lansia merupakan salah satu bentuk aktivitas fisik lansia yang bisa mengurangi tekanan darah pada lansia. Semakin aktif lansia maka akan semakin normal tekanan darahnya (Iswahyuni, 2017). Penelitian lain bahwa senam lansia mempengaruhi penurunan tekanan darah (Aji, 2015).

Berdasarkan studi pendahuluan dari kader $\begin{array}{lllll}\text { dusun Ngangkruk RT } & 01 & \text { RW } & 14\end{array}$ Gondangrejo disebutkan banyak warga yang menderita hipertensi. Hasil wawancara kepada kader posyandu lansia menyatakan bahwa belum pernah dilakukan pengukuran depresi lansia dan belum pernah ada upaya meminimalkan depresi pada lansia penderita 
hipertensi dengan senam lansia. Lima dari 18 lansia di Posyandu lansia Warga Sehat yang hadir pada saat kegiatan posyandu lansia mengatakan memikirkan tekanan darah tingginya yang seringkali menganggu aktivitas sehari hari, dan takut kalau terjadi hal yang lebih buruk, serta mengaku putus asa dan pasrah. Berdasarkan hasil observasi beberapa lansia tampak sedih dan khawatir. Tujuan penelitian untuk mengidentifikasi pengaruh senam lansia terhadap tingkat depresi pada lansia penderita.

\section{METODE PENELITIAN}

Jenis penelitian ini adalah penelitian kuantitatif eksperimen. Rancangan penelitian yang digunakan adalah quasy eksperiment dengan desain one group pre and post test without control, yang artinya peneliti hanya melakukan intervensi pada satu kelompok tanpa pembanding responden dengan pre-post test pengkuran tingkat depresi.

Populasi yang digunakan adalah Lansia penderita hipertensi di desa Ngangkruk RT 01 RW 14 Kalurahan Gondangrejo Kabupaten Karanganyar. Jumlah sampel 24 responden dengan total sampling[E1].

Intervensi yang diberikan adalah senam lansia yang dilakukan dalam 4 kali perlakuan, dengan durasi 45 menit setiap sesi. Depresi pada lansia diukur dengan menggunakan alat Geriatric Depression Scale. Alat ukur telah valid dan reliabel. Penelitian ini telah melalui uji etik dengan nomor ethical clearance 045/UKH.L.02/EC/XI/2018.

\section{HASIL DAN PEMBAHASAN}

a. Analisis Univariat

1) Tingkat depresi sebelum diberikan senam lansia

Tabel 3.1 Tingkat depresi sebelum diberikan senam lansia $(n=24)$

\begin{tabular}{lccccc}
\hline $\begin{array}{l}\text { Depresi } \\
\text { Pre senam lansia }\end{array}$ & Min & Max & Mean & Median & Std deviasi \\
\hline & 8 & 13 & 10,71 & 10,50 & 1,488 \\
\hline
\end{tabular}

\begin{tabular}{ll}
\hline $\begin{array}{c}\text { Hasil analisis Tabel 3.1 dapat dilihat } \\
\text { tingkat depresi responden sebelum }\end{array}$ & $\begin{array}{l}\text { atau depresi. } \\
\text { meningkatkan den atau depresi dapat } \\
\text { diberikan senam lansia dengan nilai mean }\end{array}$ \\
berpotensi mengalami hehingga \\
10,71 (depresi sedang) dan standar deviasi & (Kowalski, Robert E.; Burstein, 2010) \\
1,488. Rata rata lansia penderita hipertensi & Perubahan psikososial yang terjadi pada \\
mengalami depresi sedang, hal ini terjadi & masa tua akibat perubahan kognitif, kondisi \\
karena responden mengalami bertambahnya & penyakit, kehilangan peran sosial yang \\
usia, maka tingkat depresi akan semakin & dapat mengakibatkan perubahan konsep diri \\
meningkat karena bertambahnya beban & lansia yang pada akhirnya hal tersebut \\
hidup dan bertambahnya permasalahan & menjadi stressor lansia, oleh karena itu \\
hidup. Selain dari itu karena para lansia & lansia rentan mengalami masalah psikologis \\
juga penderita hipertensi, yang mana bahwa & yang umum yaitu depresi (Putri \& Fitriyani, \\
hipertensi salah satu sebabnya adalah stress & 2016).
\end{tabular}

2) Tingkat depresi sesudah diberikan senam lansia

Tabel 3.2 Tingkat depresi sesudah diberikan senam lansia $(n=24)$

\begin{tabular}{lccccc}
\hline $\begin{array}{l}\text { Depresi } \\
\text { Post senam lansia }\end{array}$ & Min & Max & Mean & Median & Std deviasi \\
\hline & 5 & 11 & 7,875 & 8,000 & 1,9407 \\
\hline
\end{tabular}

Hasil analisis Tabel 3.2 dapat dilihat tingkat depresi responden setelah diberikan senam lansia dengan nilai mean 7,875 (depresi ringan) dan standar deviasi 1,9407. Berdasarkan hasil penelitian ini bahwa rata rata atau mean dari tingkat depresi lansia sebesar 7,875, hal ini menunjukkan bahwa rata rata mengalami depresi ringan setelah dilakukan senam lansia. Para lansia yang menjadi responden setelah dilakukan senam tampak tertawa dan bahagia. Latihan fisik samgat bermanfaat untuk meningkatkan 
kesehatan dan kebugaran tubuh, selain itu juga untuk kesehatan mental. Latihan fisik, salah satunya senam mampu meningkatkan sintesa dan sekresi hormone serotonin baik dalam serum maupun dalam susunan syaraf pusat. Pengeluaran serotonin berhubungan erat dengan peningkatan mood, sehingga akan memperbaiki emosi pada kondisi depresi (Rostika, 2015)

b. Uji Normalitas

Sebelum melakukan analisis bivariat, data setiap variable diuji normalitas terlebih dahulu, hal harus dipenuhi untuk menentukan uji selanjutnya pada analisa bivariatnya. Uji normalitas pada penelitian ini menggnakan uji Shapiro-Wilk. Jika $p$ value (Sig.) $<0,05$ maka data terdistribusi tidak normal sedangkan apabila $p$ value (Sig.) > 0,05 maka data terdistribsi normal. Hasil uji normalitas shapiro wilk menunjukkan nilai pre test 0,057 dan post test 0,116 sehingga nilai $p$ value $>0,05$ maka data pre dan post test terdistribusi normal yang berarti analisa bivariat menggunakan uji Paired Sample T Test.

Tabel 3.3 Uji normalitas tingkat depresi lansia sebelum dan sesudah senam lansia $(n=24)$

\begin{tabular}{lccc}
\hline Depresi & \multicolumn{3}{c}{ Shapiro-Wilk } \\
\cline { 2 - 4 } & Statistic & df & Sig. \\
\hline pre & 0.920 & 24 & 0,057 \\
\hline post & 0,933 & 24 & 0,116 \\
\hline
\end{tabular}

c. Analisis Bivariat

Tabel 3.4 Uji bivariat Paired Sample T Test pengaruh senam lansia terhadap tingkat depresi lansia penderita hipertensi

\begin{tabular}{lc}
\hline Hasil Analisis & \\
\hline $\mathrm{t}$ & 8,792 \\
$\mathrm{Sig}$. (2-tailed) & 0,000 \\
\hline
\end{tabular}

Berdasarkan Tabel 5.4 bahwa hasil uji analisis Paired Sample T Test pada data pre dan post senam lansia menunjukkan nilai $p$ value (sig) 0,000 sehingga $p$ value (sig) < 0,05 maka $\mathrm{H}_{0}$ ditolak dan $\mathrm{H}_{1}$ diterima dengan kesimpulan ada pengaruh senam lansia terhadap tingkat depresi lansia penderita hipertensi di Posyandu Warga Sehat.

Hasil penelitian menunjukkan bahwa uji bivariat adalah uji analisis Paired Sample T Test pada data pre dan post senam lansia menunjukkan nilai $\quad p$ value (sig) 0,000 sehingga $p$ value $($ sig $)<0,05$ maka $\mathrm{H}_{0}$ ditolak dan $\mathrm{H}_{1}$ diterima dengan kesimpulan ada pengaruh senam lansia terhadap tingkat depresi lansia penderita hipertensi. Berdasarkan penelitian sebelumnya bahwa senam lansia merupakan salah satu bentuk aktivitas fisik lansia yang bisa mengurangi tekanan darah pada lansia. Disampaikan bahwa semakin aktif lansia maka akan semakin normal tekanan darahnya (Iswahyuni, 2017).

Seseorang yang mengalami depresi bisa dikarenakan kekurangan serotonin atau norepinephrine dalam otak, hormon adrenalin akan dilepaskan dan kemudian akan meningkatkan tekanan darah melalui kontraksi arteri (vasokontriksi) dan denyut jantung akan meningkat. Stres yang berlanjut, maka tekanan darah akan tetap tinggi sehingga orang tersebut akan mengalami hipertensi (Suoth et al., 2014). Senam lansia sendiri merupakan salah satu jenis olahraga yang mudah dilakukan oleh lansia karena memiliki gerakan yang sifatnya ringan. Adanya senam lansia tersebut dapat mengurangi kemurungan bahkan dapat mengontrol emosi dan meningkatkan rasa bahagia karena berjumpa dengan rekan-rekan seusia. Oleh karena itu gerakan senam lansia ini akan mampu mengatasi stress yang dialami lansia serta depresi, karena gerakan atau aktivitas yang dilakukan lansia dapat memperlancar penyaluran syaraf atau brain nuritransmitters ke dalam otak. Bahkan mampu meningkatkan noreephinephrine, dopamine, dan serotonin dalam otak.

Penelitian lain adalah hasil penelitian menunjukkan senam lansia mempengaruhi penurunan tekanan darah. Pada saat yang sama akan terjadi peningkatan serotonin yang menyebabkan peningkatan mood penderita hipertensi dengan depresi (Aji, 2015; Kowel et al., 2016; Tegawati et al., 2009) Oleh karena itu lansia penderita hipertensi yang mengalami depresi mampu memperbaiki emosi dan kondisi mental membaik dan tingkat depresi menjadi berkurang. Selain serotonin yang meningkat maka hormone adrenalin mengalami penurunan, vasodilatasi pembuluh darah, denyut jantung dan kembali normal. 


\section{KESIMPULAN}

Kesimpulan penelitian adalah ada pengaruh senam lansia terhadap tingkat depresi lansia penderita hipertensi. Lansia yang menderita hipertensi sebaiknya melakukan kegiatan aktivitas fisik salah satunya senam lansia sehingga menstimulus penurunan depresi.

\section{SARAN}

a. Setiap posyandu lansia menerapkan pelaksanaan senam lansia atau kegiatan aktivitas fisik lainnya

b. Di dalam manajemen posyandu lansia perlu dikemas secara nasional dan baku sehingga kegiatan aktivitas fisik lansia dalam bentuk senam lansia menjadi kegiatan yang diutamakan

\section{UCAPAN TERIMA KASIH}

Terimakasih kami ucapkan kepada:

a. Kader posyandu Posyandu Warga Sehat desa Selokaton yang telah membantu proses penelitian di desa Ngangkruk RT 01 RW 14 Kalurahan Gondangrejo Kabupaten Karanganyar

b. Responden lansia penderita hipertensi di Posyandu Warga Sehat

c. Pihak pihak terkait yang terlibat dalam penyusunan penelitian

\section{REFERENSI}

Aji, W. P. B. (2015). Pengaruh Senam Lansia Terhadap Tekanan Darah Pada Lansia Penderita Hipertensi Di Posyandu Lansia Dusun Banaran 8 Playen Gunungkidul. Naskah Publikasi, 12.

Indah Prasetyaningrum, Y. (2014). Hipertensi Bukan untuk Ditakuti (p. 148). https://www.google.co.id/books/edition/Hi pertensi_Bukan_untuk_Ditakuti/8uluBgA AQBAJ?hl=id\&gbpv=0

Iswahyuni, S. (2017). Hubungan Antara Aktifitas Fisik Dan Hipertensi Pada Lansia. Profesi (Profesional Islam): Media Publikasi Penelitian, 14(2), 1. https://doi.org/10.26576/profesi.155

Kementerian Kesehatan RI. (2018). Laporan Riskesdas 2018. Laporan Nasional RIskesdas 2018, 53(9), 181-222. http://www.yankes.kemkes.go.id/assets/do wnloads/PMK No. 57 Tahun 2013 tentang PTRM.pdf
Kowalski, Robert E.; Burstein, S. R. A. R. S. E. (2010). Terapi hipertensi: program 8 minggu menurunkan tekanan darah tinggi dan mengurangi risiko serangan jantung dan stroke secara alami. Qonita.

Kowel, R., Wungouw, H. I. S., \& Doda, V. D. (2016). Pengaruh senam lansia terhadap derajat depresi pada lansia di panti werda. Jurnal E-Biomedik, 4(1). https://doi.org/10.35790/ebm.4.1.2016.10 823

Kurnianto, S., Purwaningsih, \& Nihayati, H. E. (2019). Penurunan tingkat depresi pada lansia dengan pendekatan bimbingan spiritual. Jurnal Ners, 6(2), 156-163.

Livana, Susanti, Y., Darwati, L. E., \& Anggraeni, R. (2018). Gambaran Tingkat Depresi Lansia. NURSCOPE: Jurnal Keperawatan Dan Pemikiran Ilmiah, 4(4), 80-93.

Novayanti, P. E., Adi, M. S., \& Widyastuti, R. H. (2020). Tingkat Depresi Lansia yang Tinggal di Panti Sosial. Jurnal Keperawatan Jiwa, 8(2), 117. https://doi.org/10.26714/jkj.8.2.2020.117122

Nurwahidah. (2010). Jurnal Non Penelitian. 002.

Putri, S. I., \& Fitriyani, P. (2016). Gambaran Tingkat Depresi Lansia yang Melakukan Senam Di Panti Sosial Tresna Werdha di Jakarta. Jurnal Keperawatan Indonesia, 19(2), 92-99. https://doi.org/10.7454/jki.v19i2.464

Rodgers, V. (2008). Gerontological Nursing: Competencies for Care. In Journal of Clinical Nursing (Vol. 17, Issue 4, pp. 564-564). https://doi.org/10.1111/j.13652702.2006.01921.x

Rostika, F. (2015). Perbedaan Konsentrasi Serotonin Jaringan Otak Tikus Wistar (Rattus norwegicus) Yang Diberi Perlakuan Aktivitas Fisik Anaerobic Dengan Frekuensi Latihan Yang Berbeda. Prosiding Konggres NAsional IAIFI XVI, Simposium, Seminar Nasional Dan Workshop Ke XXIV, 475-480.

Santoso, Budi; Sulistiowati, Eva; Sekartuti; Lamid, A. (2013). Riset Kesehatan Dasar RISKESDAS 2013 Provinsi Jawa Tengah. In Badan Penelitian dan Pengembangan Kesehatan Kementerian Kesehatan RI (Vol. 369, Issue 1). http://dx.doi.org/10.1016/j.jsames.2011.03 
$.003 \% 0$ Ahttps://doi.org/10.1016/j.gr.2017. 08.001\%0Ahttp://dx.doi.org/10.1016/j.pre camres.2014.12.018\%0Ahttp://dx.doi.org/ 10.1016/j.precamres.2011.08.005\%0Ahttp ://dx.doi.org/10.1080/00206814.2014.902 757\%0Ahttp://dx.

Suoth, M., Bidjuni, H., \& Malara, R. (2014). Hubungan Gaya Hidup Dengan Kejadian Hipertensi Di Puskesmas Kolongan
Kecamatan Kalawat Kabupaten Minahasa Utara. Jurnal Keperawatan UNSRAT, 2(1), 105951.

Tegawati, L. M., Karini, S. M., \& Widya, R. (2009). Pengaruh Senam Lansia Terhadap Penurunan Tingkat Depresi Pada Orang Lanjut Usia. Jurnal Psikologi, 1(2), 3645. 